ARID International Journal for Science and

Technology (AIJST)

ISSN: 2662-009X

Journal home page: http://arid.my/j/aijst

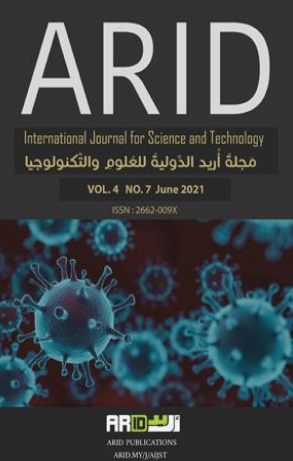

$$
\text { مَجلةُ أُريد الدَّوليةُ للعُلورج والتّكنولوجيا }
$$

\title{
Requirements for controlling the accident's cost problems for construction projects
}

\author{
Zuhair Nafea Alani
}

Architectural and Interior Design Engineering Department -College of Engineering Gulf University - Bahrain

$$
\begin{aligned}
& \text { متطلبات السيطرة على المشـاكل الكلفوية لحوادث العمل للمشاريع الإنشائية } \\
& \text { زهير نافع العاني } \\
& \text { قسم الهندسة المعمارية و التصميم الداخلي_الجامعة الخليجية ـ مملكة البحرين }
\end{aligned}
$$




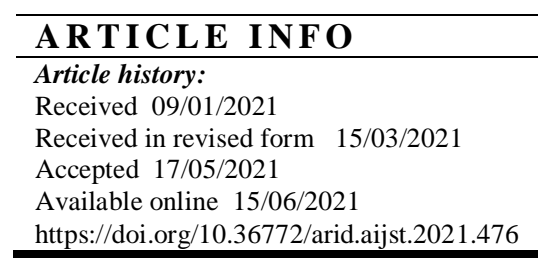

\begin{abstract}
The construction sector is one of the most accident-prone sectors during onsite work. Therefore, it increases the costs of the projects and add more amount to the budget i.e., the workers' hospitalization charges on injuries, and casualties led to it. The current study reviews the site cost issues due to the accidents caused during the construction projects with their suggested solutions. This research has reviewed thirty Sudanese Construction sector projects and analyses their results in detail to obtain the possible solutions as a part of an integrated site management system for accident cost problem (diagnosing and solving). It also used to reduce accidents, and to prevent any extra costs which might occur due to it.
\end{abstract}

Keywords: Construction projects, Site accidents, Site costs, Site management 


\section{الخلاصة}

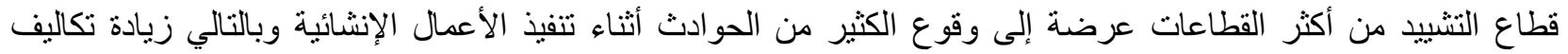

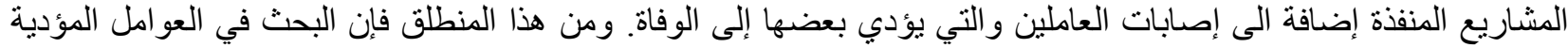

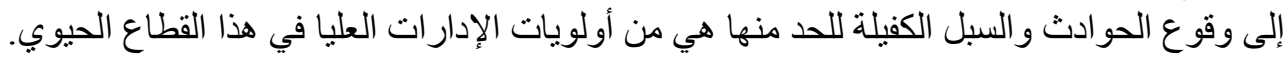
يتناول البحث شرح للمشاكل الموقعية التي تسبب في وقوع حوادث العمل و التي بالتالي تؤدي إلى زيادة في تكاليف العمال خلال التهل

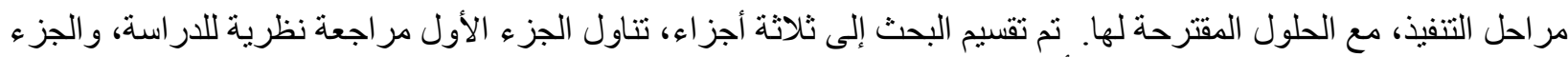

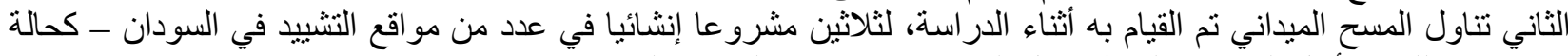

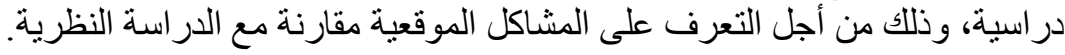

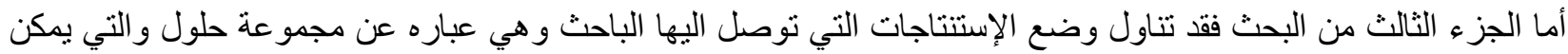

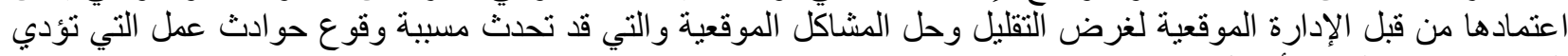
إلى زيادة في تكاليف الأعمال. الكلمات المفتاحية: المشاريع الإنشائية، حوادث العمل، التكاليف الموقعية، إدارة الموقع. 


\section{Introduction}

The construction industry has experienced a lot of occupational injuries, and construction work is considered one of the most dangerous occupations due to the dynamic and temporary nature of the workplace. Specifically, most construction work takes place outdoors and work conditions (e.g., temperature, humidity, and light conditions) and the number of required workers frequently changes, which increases the difficulty of safety management [1].

The current study has reviewed relevant literature to seek solutions of upsurge in the budget due to the onsite accidents during construction projects.

This research has been divided into three parts, the first part deal with reviewing the literature of the research, and through the second part, thirty projects, are selected from Sudanese construction sector - as a case study. These cases have been investigated to identify the site accident challenges and then compared with the literature. The third part of the research concludes a set of possible solutions as a part of an integrated site management system for accident cost problem (diagnosing and solving), to be followed by the site management, to reduce accidents, and therefore preventing any extra costs which might occur due to it.

\section{2- THE LITERATURE REVIEW}

\section{2-1:Classification of construction accidents}

Accident is defined as "any sudden, unexpected or planned emergency occurring during the work or causing what is related to it, and this includes any exposure to natural, mechanical or chemical hazards or acute stress and other risks that may lead to death, physical injury or acute illness to the injured worker. And the accident may lead to damages and damage to the facility or 
production means without injuring any of the workers. Or it may lead to injury to one or more workers in addition to damage to the facility and the means of production" [2].

\section{Some common types of construction accidents include:}

- Crane or hoist accidents. Cranes and hoists are important construction tools. However, lack of training, operator errors, and other factors can lead to serious accidents on construction sites. [3]

- Falls from heights. Scaffolding accidents, ladder accidents, roofing accidents, and other falls from heights can be lethal. [3]

- Slip and falls. A slip and fall on the ground can cause broken bones, sprains, and other injuries.

- Repetitive stress injuries. Repetitive nature of some construction work can result in repetitive stress injuries in the back, wrists, ankles, and joints. [3]

- Gas leaks, fires, and explosions. Gas leaks, fires, and explosions can be sudden and deadly. Carbon monoxide, for example, can be dangerous in a confined construction space. [3]

- Forklift accidents. Without proper training and alert operators, forklifts can be dangerous and may result in serious construction accidents. [3]

- Trench accidents. A trench collapse or an accident within a trench can be devastating. A construction worker may be trapped and unable to get out on their own. [3]

- Elevator shaft accidents. Construction workers may be at risk of falling down elevator shafts if safety precautions are not observed. [3]

- Electrocutions. Electrical equipment, overhead electrical wires, wiring, and lightning all create risks of electrocution for construction workers. [3] 
- Machinery accidents. Heavy machines perform great deal of construction operations, but these also create risk situations for construction workers either because of malfunction of machinery or operator's fault. [3].

- Struck-by accidents. Motor vehicles are common on construction sites. Construction worker is at risk of being hit by a motor vehicle or part of machinery while working on a construction site.

- Caught-between accidents. A limb of a person or entire body may get caught by a piece of equipment or crushed by the debris of a construction incident. [3]

- Exposure to hazardous or toxic chemicals. Inhalation of chemicals or toxic vapors by construction workers can cause severe respiratory problems. [3]

\section{2-2:Classification of Site Accident costs}

The cost of workday loss caused by minor occupational accidents are almost $35 \%$ of major workday losses. These costs present the importance of preventive measures for workers' health and safety in construction. [4]

Costs caused by occupational accidents are well investigated in many different studies and they are subdivided into two categories as:

Direct costs include Medical costs, ambulance fee, Doctor's fees, hospital fee, rehabilitative services, cost of medication, therapy, insurance compensation payment to the injured worker [5].

Indirect costs include workday loss, working time loss in workplace, time loss for investigating the accident and legal processes, pausing the production after the accident, delay in workflow and program, damage in working machines or stopping to use these machines, low efficiency of 
workers, loss of reputation for the company, fine payments for late delivery. Thus, it is indicated that indirect costs are much higher than the direct costs in total. [4]

\section{2-3: The Factors Affecting Site Accidents Costs and their applicable solutions.}

\section{2-3-1: The Factors Affecting Site Accidents Costs:}

2-3-1-1: Excavations Works: the most affecting factors which can cause accidents during excavations are: [6]

- Unshoring the sides of excavation or sloping to the angle of repose may causes cave-in.

- Equipment operates near the top edge of the excavation.

- Keeping or storing the materials near the edge of the excavation.

- Electrical cables or and flammable gases pipes damaged during excavation causing possible hazards.

- No emergency exit is provided for employees working in a trench deeper than $4 \mathrm{ft}$.

2-3-1-2: Individual falls: the unsecured railings will be the most affective factor for increasing the risk of accidents. [6]

2-3-1-3: Steel erections:_steel erection is very hazardous construction task, the factors which can cause accidents during steel erection on site are: [6]

- Workers are not provided with gloves, hard hats, and eye protection when they engaged in welding, cutting, and chipping operations.

- Shortage of scaffolds, or scaffolds without guard rails and safety belts can cause individual falls.

- No safety nets are provided when working on high places above the ground.

- weather is responsible for many of the hazards at the steel erection sites.

\section{2-3-1-4: Equipment operations:}

The most factors which might increase accidents due to equipment operations are: [6] 
-Using the equipment in improper purpose.

-Employing unexperienced operators.

- Exceeding the equipment design limits.

-loading the equipment in a way that affects the safety of driving or operating them.

- The position of the equipment near the edge of the excavation when unloading.

-Bad site illumination.

\section{2-3-1-5: Marine or over-water construction:}

Marine or over-water construction presents all the usual construction hazards plus additional hazards posed by the marine environment, these additional hazards include slippery surfaces, increased tripping, and height hazards, as well as weather and wave actions. Factors which can add other risk of accidents are: [6]

-Bad illumination.

-Lack of ramps or walkways.

-unguarded decks or surfaces over water.

\section{2-3-1-6: Environmental Health in construction:}

The major Environmental Health problems encountered in construction consist of noise, dust, toxic materials, heat and cold. [6]

\section{2-3-2: applicable solutions to be considered to avoid accidents are:}

\section{2-3-2-1: For Excavations Works:}

- Sides of excavations should be properly shored by one of the shoring systems, such as: sheeting, lagging, or sheet piling [7].

-When employees are required to work in a trench $4 \mathrm{ft}(1.2 \mathrm{~m}$.) or more in depth, provide an adequate means of emergency exit located with (7.6 m.) of the worker. 
-Avoid the operation of equipment near the top edge of an excavation because this increases the chance of slope failure.

- Materials should not be stored near the edge of an excavation to decrease the chance of slop failure when workers are required to enter the excavation. No spoil or other material may be stored within $(0.6 \mathrm{~m}$.) of the edge of the excavation.

-Watch out for buried lines and containers when excavation. Possible hazards include toxic and flammable gasses, electricity and collapse of side slopes may occur due to sudden release of liquids.

\section{2-3-2-2: For individual falls:}

The procedures to be followed to prevent workers failure are: [8]

-Properly guard all opening above ground level.

-Provide guard rails, safety lines, safety belts, and/or safety nets for workers on scaffolds or steel work.

-Temporary structures should be properly designed, constructed, and braced.

\section{2-3-2-3: For steel erections:}

To prevent accidents during steel erections, the following steps should be followed: [9] -workers engaged in welding, cutting, and chipping operations should be provided with hard hats, gloves, and eye protection.

-Prevent workers from falls from high places during erection by:

* Providing, whenever possible, temporary floors and scaffolds with rails.

* Providing lifelines and safety belts when guard rails are not feasible.

* Providing safety nets where the potential fall exceeds $(7.6 \mathrm{~m}$.) or two stories.

\section{2-3-2-4: For Equipment operations:}

-Machines should be equipped with the required safety features and operators use seat belts when provided. 
-The designed limits of equipment should not be exceeded, especially when operating cranes.

-Workers not to be allowed to ride on equipment unless proper seating is provided.

-Provide good site illumination to have clear roads to avoid accidents during transport.

-Ensuring that any guards or safety devices removed during equipment repair are promptly replaced. [7]

\section{2-3-2-5: For Marine or over-water construction:}

-Ramp or safe walkway must be provided.

- Access ways must be adequately illuminated free of obstructions.

-Working areas should have nonslip surfaces.

-Workers on unguarded decks or surfaces over water must wear approved life jackets or buoyant vests. Life rings and a rescue boat must also be available.

-Workers more than $25 \mathrm{ft}$. (7.6m.) above a water surface must be protected by safety belts and safely nets. [7]

\section{2-3-2-6: For Environmental Health in construction:}

-Workers who are concerned with cutting materials, especially asbestos, should be provided with noise cabs to avoid them from toxic dust effect.

-For people working in tunnels, dust problems can be avoided by ventilate a tunnel. Blasting, mucking, and using water instead of air to remove the cuttings to avoid dust caused by drilling.

-Methods of reducing heat effect on workers include the use of mechanical equipment, scheduling hot work for the cooler part of the day, use of sun shields, providing cool rest areas, providing water supply easily accessible to workers, and the use of proper hot-weather clothing. 
-The provisions of workers with adequate clothing and warming areas will be successful requirements for cold weather construction.

- Giving the workers adequate rest allowances to avoid stresses and accidents due to working more than allowable hours under extreme temperature in hot weather construction. [6]

\section{3- Controlling accident costs:}

In the light of the above discussed facts, it seems crucial that onsite accident costs must also be included in the monthly report of the actual costs of the project along with the monthly costs of main elements such as (labor, machinery, materials, incentives, contractors, and subcontractors work etc.)

Safety is an important part of project management, and it is no less important than planning, scheduling of work, estimating work quantities, and controlling costs, and it must be considered. Achieve safety in the design stage and during the project implementation stages. Accidents do not .affect workers only, but also their families [10]

So, to control accidents costs during the implementation of the work, the "safety program" can be a reason for preventing these accidents [11].

\section{THE FIELD WORK}

Through this part of the research, a survey has been conducted on thirty selected Sudanese projects to identify the actual accidents site rising cost concerns. The field work was also added to get the in-depth information from site management experts in relation to the accidents during construction, and their suggested solutions for these problems (if any) to compare with the consulted literature. 


\section{4-1 The characteristics of the respondents}

Table (1) illustrates the respondents (experts) selected for the survey. The table below shows their years of experience, which is ranged from 5-40 years:

- $\quad 40 \%$ of experience have (8-15) years.

- $13 \%$ of experience have (16-20) years.

- $30 \%$ of experience have (21-25) years.

- $17 \%$ of experience have (26-40) years.

Majority (60\%) of the respondents have more than 16 years of experience. Most (63\%) of the respondents are civil engineers, while $20 \%$ are architectural, and $17 \%$ respondents are mechanical and electrical engineers. A large number (73\%) of them are working as site and project managers, which provided substantial information and in-depth knowledge of field experience which is quite useful for the research undertaken.

\section{4-2 Preparing the Questionnaire List (Q.L.)}

The review of literature related to the Accident site cost problems has been carried out from the thirty Sudanese survey projects. In depth field knowledge from the survey projects have been obtained from the respondents.

The Questionnaire List (Q.L.) has been prepared from the literature which includes all the site cost challenges (factors) that are affecting the accident site costs with their possible solutions that would reduce these costs.

As a result of eliciting most of the problems that might increase accident site costs, through the (Q.L.), the total number of these problems (factors) have finally reached in number to (24), distributed as follows:

1- Excavations, 6 problems

2- Individual fall, 6 problems

3- Work on water, 2 problem 
4- Scaffolding, 3 problems

5-Work environment, 7 problems

\section{4-3 The Analysis of the tabulated results}

The results which have been concluded from the (Q.L.) answers were analyzed, and tabulated, as shown in Table (2) and Table (3), the following figures were calculated and presented for each of the thirty selected projects.

A- The number of existed site cost problems found in the selected research projects.

B- The percentage of existing site cost problems out of total known problems.

C- The number of problems that were addressed and solved during the implementation by the management of these projects.

D- The percentage of site cost addressed and resolved.

E- The number of problems that still exist that have not been addressed and resolved, and their types and percentage.

\section{4-4 Analysis of percentages table.}

Tables (2) shows the number of existing site cost problems, and their percentages.

While Table (3) shows Number of issues, solved by project management, and problems that still exist, and their percentages, where Only $(60 \%)$ of the selected projects have solved more than $50 \%$ of their cost problems.

Also, table (3) indicates the affecting factors (problems) on site costs such as: scaffolding, individual fall, excavation. Table (4) shows the percentages of these problems in the selected projects according to their significant effectiveness on site costs.

A- $93 \%$ of the projects still have unsolved problems regarding scaffolding.

B- $90 \%$ of the projects still have unsolved problems regarding individual fall at work.

C- $83 \%$ of the projects still have unsolved problems regarding excavation work. 
D- $70 \%$ of the projects still have unsolved problems regarding work environment.

Figure (1) shows the number of problems which cause site accidents and still exist in the selected Projects.

The analysis of Tables (2) and (3) helps the top management in diagnosing and evaluating the efficiency and performance of project site management in identifying and solving cost problems, through knowing who can solve most of their cost problems (specially the most effective on increasing site costs), and managers who have the largest percentage of problems that have unsolved.

If the percentage of unsolved problems exceeds $25 \%$ in any construction project, this gives a good indication to top management in identify the site cost problems that will have a significant impact in increasing the total costs of the project, and thus effective corrective measures are taken to solve these problems.

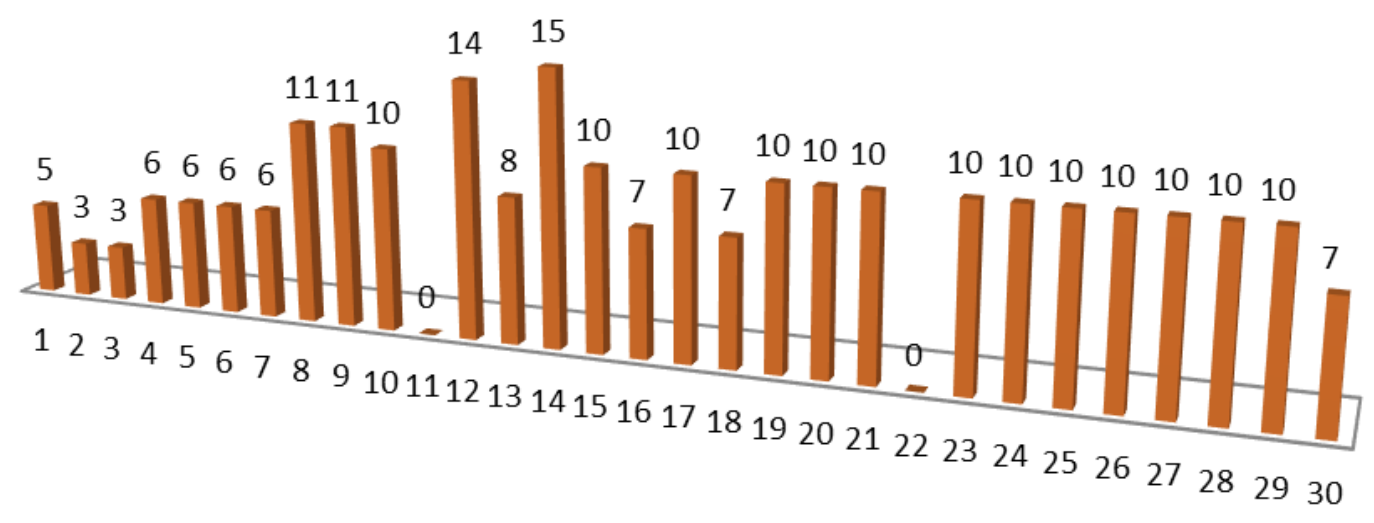

Figure(1): unsolved Accident cost problems in 30 construction projects 
Table(1): Respondence characteristics

\begin{tabular}{|c|c|c|c|c|c|}
\hline $\begin{array}{c}\text { Projects } \\
\text { Numbers }\end{array}$ & Years of experience & $\begin{array}{c}\text { Projects } \\
\text { Numbers }\end{array}$ & specialization & $\begin{array}{c}\text { Projects } \\
\text { Numbers }\end{array}$ & position \\
\hline $\begin{array}{c}6,7,11,15,16,1 \\
7,22,23,26,28, \\
29,30\end{array}$ & $8-15$ & $\begin{array}{c}1,2,3,5,10,11,12 \\
, 13,14,19,20,22, \\
23,24,25,26,27, \\
29,30\end{array}$ & Civil engineer & $1,7,8,17,18,27$ & $\begin{array}{c}\text { Project } \\
\text { manager }\end{array}$ \\
\hline $1,13,20,24$ & $16-20$ & $4,8,16,18,21,28$ & Architect & $\begin{array}{c}2,6,10,11,12,13, \\
15,19,20,22,23, \\
24,25,26,28,29\end{array}$ & $\begin{array}{c}\text { Site } \\
\text { manager }\end{array}$ \\
\hline $\begin{array}{c}2,3,4,5,8,10,12 \\
, 18,27\end{array}$ & $21-25$ & 6,9 & $\begin{array}{c}\text { Mechanical } \\
\text { engineer }\end{array}$ & $3,9,14,16,21,30$ & Designer \\
\hline $9,14,19,21,25$ & $26-30$ & $7,15,17$ & $\begin{array}{c}\text { Electrical } \\
\text { engineer }\end{array}$ & 4,5 & planner \\
\hline
\end{tabular}

Table(2): number of problems exist for each project and their percentages.

\begin{tabular}{|c|c|c|c|}
\hline $\begin{array}{c}\text { Projects } \\
\text { Numbers }\end{array}$ & $\begin{array}{c}\text { Total number of } \\
\text { problems }\end{array}$ & $\begin{array}{c}\text { Number of problems } \\
\text { exist (in each project) }\end{array}$ & $\begin{array}{c}\text { \% of problems exist } \\
\text { (in each project) }\end{array}$ \\
\hline $1,10,15,16,21,30$ & 24 & 20 & $\% 83$ \\
\hline $2,8,14,18,28$ & 24 & 19 & $\% 79$ \\
\hline $3,12,17,23,25$ & 24 & 22 & $\% 92$ \\
\hline $4,5,9,24,27$ & 24 & 21 & $\% 88$ \\
\hline $6,13,19,26,29$ & 24 & 18 & $\% 75$ \\
\hline 7,20 & 24 & 17 & $\% 71$ \\
\hline 11 & 24 & 15 & $\% 63$ \\
\hline 22 & 24 & 14 & $\% 58$ \\
\hline
\end{tabular}


Table(3): Number of problems solved by project management, and problems that still exist and their types.

\begin{tabular}{|c|c|c|c|c|c|}
\hline $\begin{array}{l}\text { Project } \\
\text { No. }\end{array}$ & $\begin{array}{l}\text { Number of } \\
\text { problems exist } \\
\text { in each project }\end{array}$ & $\begin{array}{l}\text { Number of } \\
\text { problems solved } \\
\text { in each project }\end{array}$ & $\begin{array}{l}\text { \% of problems solved } \\
\text { in each project }\end{array}$ & $\begin{array}{l}\text { Number of } \\
\text { unsolved problems } \\
\text { in each project }\end{array}$ & $\begin{array}{l}\text { Number and Type of unsolved problems } \\
\text { in each project }\end{array}$ \\
\hline 12 & 22 & 8 & $\% 36$ & 14 & $\begin{array}{l}\text { (4) problems regarding individual Fall } \\
\text { (2) problems regarding Scaffolding } \\
\text { (5) problems regarding excavation } \\
\text { (1) problems regarding work environment } \\
\text { (2) problems regarding work on water }\end{array}$ \\
\hline 14 & 19 & 4 & $\% 21$ & 15 & $\begin{array}{l}\text { (3) problems regarding individual Fall } \\
\text { (3) problems regarding Scaffolding } \\
\text { (4) problems regarding excavation } \\
\text { (5) problems regarding work environment }\end{array}$ \\
\hline 8 & 19 & 8 & $\% 42$ & 11 & \multirow[t]{2}{*}{$\begin{array}{l}\text { (3) problems regarding individual Fall } \\
\text { (2) problems regarding Scaffolding } \\
\text { (4) problems regarding excavation } \\
\text { (2) problems regarding work environment }\end{array}$} \\
\hline 9 & 21 & 10 & $\% 48$ & 11 & \\
\hline 10,21 & 20 & 10 & $\% 50$ & 10 & \multirow{2}{*}{$\begin{array}{l}\text { (3) problems regarding individual Fall } \\
\text { (2) problems regarding Scaffolding } \\
\text { (3) problems regarding excavation } \\
\text { (2) problems regarding work environment }\end{array}$} \\
\hline 26,29 & 18 & 8 & $\% 44$ & 10 & \\
\hline 15 & 20 & 10 & $\% 50$ & 10 & \multirow{3}{*}{$\begin{array}{l}\text { (3) problems regarding Scaffolding } \\
\text { (3) problems regarding excavation } \\
\text { (1) problems regarding work environment } \\
\text { (3) problems regarding individual Fall }\end{array}$} \\
\hline 19 & 18 & 8 & $\% 44$ & 10 & \\
\hline 20 & 17 & 7 & $\% 41$ & 10 & \\
\hline 23,25 & 22 & 12 & $\% 55$ & 10 & $\begin{array}{l}\text { (2) problems regarding individual Fall } \\
\text { (3) problems regarding Scaffolding } \\
\text { (4) problems regarding excavation } \\
\text { (1) problems regarding work environment }\end{array}$ \\
\hline
\end{tabular}


ARID International Journal for Science and Technology (AIJST) VOL: 4, NO 7, June 2021

\begin{tabular}{|c|c|c|c|c|c|}
\hline 17 & 22 & 12 & $\% 55$ & 10 & $\begin{array}{l}\text { (2) problems regarding individual Fall } \\
\text { (3) problems regarding Scaffolding } \\
\text { (4) problems regarding excavation } \\
\text { (1) problems regarding work environment }\end{array}$ \\
\hline 27 & 21 & 11 & $\% 52$ & 10 & \multirow{3}{*}{$\begin{array}{l}\text { (3) problems regarding individual Fall } \\
\text { (4) problems regarding Scaffolding } \\
\text { (3) problems regarding excavation }\end{array}$} \\
\hline & & & & & \\
\hline 28 & 19 & 9 & $\% 47$ & 10 & \\
\hline 24 & 21 & 11 & $\% 52$ & 10 & $\begin{array}{l}\text { (2) problems regarding individual Fall } \\
\text { (2) problems regarding work on water } \\
\text { (3) problems regarding excavation } \\
\text { (2) problems regarding work environment } \\
\text { (1) problems regarding Scaffolding }\end{array}$ \\
\hline 16,30 & 20 & 13 & $\% 65$ & 7 & $\begin{array}{l}\text { (3) problems regarding individual Fall } \\
\text { (2) problems regarding Scaffolding } \\
\text { (4) problems regarding excavation } \\
\text { (2) problems regarding work environment }\end{array}$ \\
\hline 18 & 19 & 12 & $\% 63$ & 7 & $\begin{array}{l}\text { (2) problems regarding individual Fall } \\
\text { (2) problems regarding Scaffolding } \\
\text { (2) problems regarding excavation } \\
\text { (1) problems regarding work environment }\end{array}$ \\
\hline 13 & 18 & 10 & $\% 56$ & 8 & $\begin{array}{l}\text { (3) problems regarding individual Fall } \\
\text { (1) problems regarding Scaffolding } \\
\text { (2) problems regarding excavation } \\
\text { (2) problems regarding work environment }\end{array}$ \\
\hline 4,5 & 21 & 15 & $\% 71$ & 6 & \multirow{3}{*}{$\begin{array}{l}\text { (2) problems regarding individual Fall } \\
\text { (2) problems regarding Scaffolding } \\
\text { (2) problems regarding excavation }\end{array}$} \\
\hline 6 & 18 & 12 & $\% 67$ & 6 & \\
\hline 7 & 17 & 11 & $\% 65$ & 6 & \\
\hline 1 & 20 & 15 & $\% 75$ & 5 & $\begin{array}{l}\text { (2) problems regarding Fall } \\
\text { (2) problems regarding Scaffolding } \\
\text { (1) problem regarding Work environment }\end{array}$ \\
\hline 2 & 19 & 16 & $\% 84$ & 3 & $\begin{array}{l}\text { (1) problems regarding Scaffolding } \\
\text { (2) problems regarding Work environment }\end{array}$ \\
\hline
\end{tabular}


ARID International Journal for Science and Technology (AIJST) VOL: 4, NO 7, June 2021

\begin{tabular}{|c|c|c|c|c|c|}
\hline 3 & 22 & 19 & $\% 86$ & 3 & $\begin{array}{l}\text { (2) problems regarding individual Fall } \\
\text { (1) problems regarding Scaffolding }\end{array}$ \\
\hline 11 & 15 & 15 & $\% 100$ & 0 & $\% 0$ \\
\hline 22 & 14 & 14 & $\% 100$ & 0 & $\% 0$ \\
\hline
\end{tabular}

Table(4): the types and percentages of problems according to their significant effectiveness on site costs

\begin{tabular}{|l|c|c|c|c|c|}
\hline & $\begin{array}{c}\text { Problems } \\
\text { regarding } \\
\text { Scaffolding }\end{array}$ & $\begin{array}{c}\text { Problems } \\
\text { regarding } \\
\text { Individual falls }\end{array}$ & $\begin{array}{c}\text { Problems } \\
\text { regarding } \\
\text { excavation }\end{array}$ & $\begin{array}{c}\text { Problems } \\
\text { regarding } \\
\text { Work } \\
\text { environment }\end{array}$ & $\begin{array}{c}\text { Problems } \\
\text { regarding } \\
\text { Work on } \\
\text { water }\end{array}$ \\
\hline $\begin{array}{l}\text { Projects } \\
\text { No. }\end{array}$ & $1,2,3,4,5,6,7,8,9,10$, & $1,3,4,5,6,7,8,9,10$, & $4,5,6,7,8,9,10,12$, & $1,2,8,9,10,12,13$, & 12,24 \\
& $12,13,14,15,16,17$, & $12,13,14,15,16,17$, & $13,14,15,16,17,18$, & $14,15,16,17,18,19$, & \\
& $25,26,27,21,23,24$, & $18,19,20,21,23,24$, & $19,20,21,23,24,25$, & $20,21,23,24,25,26$, & 29,30 \\
$25,26,27,28,29,30$ & $26,27,28,29,30$ & & \\
\hline $\begin{array}{l}\text { No. of } \\
\text { projects } \\
\text { (out of 30) }\end{array}$ & 28 & 27 & 25 & 21 & 2 \\
\hline $\begin{array}{l}\text { \% of } \\
\text { projects } \\
\text { (out of 30) }\end{array}$ & $93 \%$ & $90 \%$ & $83 \%$ & $70 \%$ & $6 \%$ \\
\hline
\end{tabular}

\section{5- THE CONCLUSION}

Thus, in a nutshell, the most significant affecting factors that cause site accidents, which led to extra site costs, are those related to Excavations, Individual falls, Scaffolding, and Work environment.

Only (60\%) of the selected projects have solved more than $50 \%$ of their cost problems. The top management should address the above-mentioned entities in mind to identify and solve some or all their cost problems related to work accidents.

This guide can be used as an efficient evaluation parameter. This evaluation would be a good incentive to encourage project managers to reduce site cost problems during the implementation of construction work. 
-As a method for monitoring and controlling site costs by diagnosing the most significant accidents, cost problems for each project, so that the top management can take the proper action to rectify such problems quickly to save costs.

-Practicing safety program may be considered as the remedy to reduce the site accidents costs. 


\section{REFERENCES}

1- K. Yang, K. Kim, S. Go, "Towards Effective Safety Cost Budgeting for Apartment Construction: A Case Study of Occupational Safety and Health Expenses in South Korea", an Article, https://www.mdpi.com/journal/sustainability/ 13/ 1335. (Accessed: Jan. 27, 2021).

2- Massoudi Kulthum, Mokrin Heba, "Work Accidents, Their Causes and Methods of Reducing them", research paper, "Altaamin lilearab", www. @insurance4arabs, (Accessed December 2013).

3- B. V. Ova," Best practices to improve construction site safety, in the specific conditions of processing plant building", University of Mining and Geology "St. Ivan Rilski", 1700 Sofia, Bulgaria, MATEC Web of Conferences (305) (00014) (2020) - 2.

4- F. Yilmaz and U. B. Çelebi," The Importance of Safety in Construction Sector", Business and Economics Research Journal Volume (6) Number (2) (2015)- 26.

5- K.K. Bentil." The impact of construction Related Accidents on the cost and productivity of building Construction Projects”, International council for Building Research Studies and Documentation (CIB), Vol. (6) (1990) -15.

6- R. Alani and Z.N. Alani " Having an efficient management system for controlling accident site cost problems of Iraqi projects", The First Engineering Scientific Conference, Civil Engineering Research Program, College of Engineering, Anbar University, Ministry of Higher Education and Scientific Research, Iraq, Sep. (1998).

7- S.W. Nunnaly, "Construction Methods and Management" $2^{\text {nd }}$ Ed. By prentice-Hall, Inc. New Jersey,1987.

8- C. Hendrickson, and T. Au, "Project Management for Construction" By prentice-Hall, Inc. USA, 1989.

9- W. Hammer, “Occupational Safety Management and Engineering”, By Prentice-Hall, Inc. New Jersey,1976.

10- Garold D. Oberlender," Project Management for Engineering and Construction”, $2^{\text {nd }}$ Edition, McGraw- Hill International Editions, Civil Engineering Series, Singapore,2000.

11- Robert L. Peorifoy, Clifford J. Schexnayder, Robert L. Schmitt, Avida Shapira, "Construction Planning, Equipment, and Methods", $9^{\text {th }}$ Edition, McGraw- Hill Education, New York, 2018. 